in vivo $35: 699-705(2021)$

doi:10.21873/invivo.12310

Review

\title{
Regenerative Therapy Using Umbilical Cord Serum
}

\author{
NAGARAJAN MAHARAJAN ${ }^{1,2^{*}}$, GWANG-WON CHO ${ }^{1,2^{*}}$, JI HYUN CHOI ${ }^{3}$ and CHUL HO JANG ${ }^{4}$ \\ ${ }^{1}$ Department of Biology, College of Natural Science, Chosun University, Gwangju, Republic of Korea; \\ ${ }^{2}$ Department of Life Science, BK21-Plus Research Team for Bioactive Control Technology, \\ Chosun University, Gwangju, Republic of Korea; \\ ${ }^{3}$ Department of Obstetrics and Gynecology, Chosun University School of Medicine, Gwangju, Republic of Korea; \\ ${ }^{4}$ Department of Otolaryngology, Chonnam National University Medical School, Gwangju, Republic of Korea
}

\begin{abstract}
Regenerative medicine is a branch of medicine that incorporates tissue-engineering, biomaterials, and cell therapy approaches to replace or repair damaged cells and tissues. Umbilical cord serum (UCS) is an important liquid component of cord blood, which has a reliable source of innumerable growth factors and biologically active molecules. Usually, serum can be prepared from different sources of blood. In therapeutic application, cord serum can be prepared and used in the form of eye drops for the treatment of severe dry eye diseases, ocular burns, glaucoma, persistent corneal epithelial defects and neurotrophic keratitis. In addition, cord serum combined with synthetic bio scaffold materials is used to regenerate different types of tissues including tympanic membrane regeneration, bone regeneration and nerve regeneration. Absence of animal origin viruses and bacteria, lack of xenoproteins and cost-effective features make cord serum a feasible choice as replacement of fetal bovine serum in cell culture techniques. Thus, this review emphasizes the role of cord serum in regenerative therapy and clinical uses.
\end{abstract}

Umbilical cord (UC) is a biological leftover obtained during parturition. Although it is an excess material, it has many treasures in it. During pregnancy, umbilical cord acted as a

This article is freely accessible online.

*These Authors contributed equally to this study.

Correspondence to: Chul Ho Jang, MD, Ph.D., Department of Otolaryngology, Chonnam National University Hospital, Gwangju, Republic of Korea. Tel: +82 622206774, e-mail: chulsavio@hanmail.net

Key Words: Umbilical cord serum, growth factors, cytokines, regeneration, review. channel between mother and developing fetus. This structure permits the transfer of nutrients and oxygen from the maternal into fetal circulation whereas concurrently the excretion of waste materials from fetal circulation to be removed maternally. Umbilical cord blood (UCB) primarily enriched with a high number of hematopoietic stem cells/progenitor cells. Therefore, it is one of the preferred choices of grafts for allogenic hematopoietic stem cell transplantation (HSCT) in leukemic condition $(1,2)$. UCB comprises not only hematopoietic stem cells, also has several types of nonhematopoietic stem/progenitor cells including mesenchymal stromal cells (MSCs), endothelial progenitor cells (EPCs), neural progenitor cells (NPCs), multi-lineage progenitor cells (MLPCs) and unrestricted somatic stem cells (USSCs). Hence, UCB is an attractive source for tissue repair mechanism, allogenic transplantation and regenerative medicine (3).

Interestingly, a chief milestone of umbilical cord blood is its liquid composition namely umbilical cord serum (UCS) and plasma (UCP). The main difference of these fluids is presence or absence of clotting factors (serum lacks clotting factors whereas plasma has clotting factors). Cord serum contains rich sources of growth factors, neurotrophic factors and cytokines with wound healing, anti-inflammatory, antiaging and anti-apoptotic properties (4). Predominantly, cord serum used to relieve irritation or dryness of the ocular surface and maintain ocular epithelial tissue to be healthy and moisture than artificial teardrops. In clinical trials, cord serum successfully applied in the treatment of corneal epithelial wound healing, dry eye syndromes, recurrent corneal erosions and ocular surface diseases. Besides this, the topical use of cord serum research has increased in different regeneration studies including bone regeneration, tympanic membrane regeneration, tracheal regeneration and nerve regeneration (5-9). Moreover, some of the findings reported that the existence of molecular markers in cord serum may reveal an early diagnosis of neurodevelopmental 
dysfunction or disorder in newborn babies (10). Additionally, cord serum used as a potential media supplement for cell growth, proliferation, migration and differentiation in cell culture applications. Therefore, we have highlighted the role of UCS in regeneration therapy and its clinical uses.

\section{Preparation of Umbilical Cord Serum}

The isolation of human UCS is much easier than fetal bovine serum. After delivery, cord blood immediately collected from pregnant mothers in a sterile container without anti-coagulants. Before procurement, respective umbilical cord donors must give their written consent. Under laboratory settings, cord blood donor samples need to be screened for contagious viral pathogens such as human immunodeficiency virus (HIV), hepatitis $\mathrm{B}$ and $\mathrm{C}$ viruses (HBV, HCV). The collected virusfree cord blood is allowed to clot for two to four hours room temperature incubation followed by centrifugation process at desire rpm or ref conditions (may vary with protocols). After centrifugation, a yellow color liquid (serum) supernatant is carefully isolated into a new sterile tube and remaining sediment of red blood cells, and other cell debris must be discarded. In order to remove donor-to-donor variations, heat inactivation must be carried out at $56^{\circ} \mathrm{C}$ for 30 minutes in collected sera followed by filtration and preservation at $-20^{\circ} \mathrm{C}$ or $-80^{\circ} \mathrm{C}$ for further experimental use (11-13).

\section{Reservoir of Growth Promoting Factors}

Growth factors are naturally occurring biological molecules capable of stimulating new cell growth at the damaged or injured sites, serving as signaling molecules in cell-cell communication, regulating a number of cellular processes, and enhancing cell proliferation. Human peripheral blood serum, platelet-derived products, cord plasma and cord serum are rich sources of different growth-promoting factors. Among them, umbilical cord serum boasts their regenerative efficacy due to the presence of vascular endothelial growth factor (VEGF), epidermal growth factor (EGF), plateletderived growth factor (PDGF), fibroblast growth factor (FGF), transforming growth factor (TGF), hepatocyte growth factor (HGF), insulin like-growth factor (IGF) and nerve growth factor (NGF) etc. In addition to these growth factors, it has different cytokine/chemokine molecules, neurotrophic factors and biologically active substances $(4,14)$ and their biological roles have discussed in Tables I and II. Thus, the application of UCS has increased in various regenerative approaches and cell culturing techniques.

\section{Regeneration}

Regeneration is an essential biological process for every organism. It is mediated by the presence of enormous biological and physiological factors surrounding the cellular microenvironment. Herein, the use of cord serum associated with different regeneration studies are discussed.

\section{Umbilical Cord Serum in Ocular Regeneration}

Usually, natural tears contain sufficient growth factors, neurotrophic factors and vitamin A that are vital for the proliferation and maturation of the normal ocular epithelium and that can keep the ocular epithelial surface healthy. In dry eye disease cases, eyes are able to produce enough tears for the moisturization and cleansing function. Artificial ear drops including cyclosporine $A$ and corticosteroids, therapeutic lenses and protective goggles have been used for this dry eye condition. Nevertheless, in the past few years, blood-derived products such as autologous serum and cord blood serum have been introduced in the treatment of these types of ocular ailments. Initially, autologous serum eyedrops were assumed to provide essential tear elements and growth factors in the treatment of persistent corneal epithelial defect (15). Later, researchers found that cord serum contains more growth factors and neurotrophic factors than autologous serum $(14,16)$. The first trial of cord serum established in persistent corneal epithelial defects patients by Vajpayee et al. In that trial, most of the UCS treated patients exhibited higher healing rates in the defect areas than the autologous serum-treated group (17). The reason may be that presence of growth factors are probably higher in the UCS than autologous serum, which may enhance significant migration and proliferation of epithelial cells that consequently lead to a faster re-epithelialization. Yoon et al. first confirmed that cord blood serum comprises a higher level of crucial tear elements, neurotrophic factors, biological substances and growth factors than autologous serum and they are effectively used to improve the symptoms of neurotrophic keratitis, severe dry eye syndrome and persistent corneal defects $(14,16,18,19)$. To assess the efficacy and safety of UCS eye drops in dry eye associated graft-versus-host-disease (GVHD), recruited patients were treated with $20 \%$ cord serum eye drops. After two months of UCS treatment observation, patients showed a significant improvement in corneal sensitivity, corneal staining score and tear film breakup time and were maintained by after six months of treatment (20). Furthermore, a combined therapy of regenerating agent (RGTA) with cord serum eyedrops has been developed for a corneal disease patient who is resistant to conventional treatment (21). This combination therapy could strengthen the healing process and be considered a new therapeutic option for eye degenerative diseases. From overall observations, cord serum eyedrops could be an effective and safest treatment for eye diseases in clinical evaluation. 
Table I. Major growth factors in UCS and their biological function in regeneration.

\begin{tabular}{ll}
\hline Growth factors & Biological function \\
\hline $\begin{array}{l}\text { Vascular endothelial growth factor (VEGF) } \\
\text { Fibroblast growth factor (FGF) }\end{array}$ & $\begin{array}{l}\text { Potent angiogenic factor; facilitates angiogenesis }(4,43) \\
\text { Promotes fibroblast cell proliferation, epithelial cells proliferation, and neural stem cells } \\
\text { proliferation; involved in wound healing (44) }\end{array}$ \\
$\begin{array}{l}\text { Majorly contributes in blood vessel formation; involved in wound healing process (4, 45) } \\
\text { Hepatocyte growth factor (HGF) }\end{array}$ & Stimulates mitogenesis, angiogenesis and tissue regeneration $(46,47)$ \\
Epidermal growth factor (EGF) & Essential factor for epithelial cell proliferation and wound healing (16) \\
Nerve growth factor (NGF) & Essential neurotrophic factor for the growth, survival and maintenance of sensory nerves (48) \\
Transforming growth factor (TGF) & Important factor for extracellular matrix formation and tissue homeostasis; crucial role \\
& in stem cell differentiation (45, 49, 50) \\
Insulin-like growth factor (IGF) & Important factor for prenatal and postnatal development of a fetus; play a significant role \\
& in stem cells growth and proliferation; also facilitates corneal regeneration $(51,52)$
\end{tabular}

Table II. Major chemokine/cytokines in UCS and their biological function in regeneration.

\begin{tabular}{ll}
\hline Chemokine/cytokines & Biological function \\
\hline Stem cell factor (SCF) & Important factor for hematopoietic progenitor cell proliferation, migration and survival (53) \\
Interleukin-8 & Chemotactic inducing factor; potent promoter of angiogenesis (54, 55) \\
Interleukin-9 & Key regulator for variety of hematopoietic cells; stimulates cell proliferation (56) \\
Interleukin-12 & Activator of T-lymphocyte growth and function; involved in immune responses (57) \\
Interleukin-17 & Mediator of pro-inflammatory responses; function linked with many autoimmune diseases (58) \\
C-X-C motif chemokine 10 (IP-10) & Regulates cell growth and proliferation and angiogenesis (59) \\
C-X-C motif ligand 9 (MIG) & Regulator of immune cell migration and activation (60) \\
C-X-C motif ligand 1 (GRO- $\alpha)$ & Involved in wound healing and inflammatory processes (61) \\
\hline
\end{tabular}

\section{UCS in Tympanic Membrane Regeneration}

Tympanic membrane (eardrum) is a thin membrane found in the middle ear, which separates the outer ear from the middle ear and acts as a boundary between them. The membrane could be injured or damaged due to many external causes. The majority of acute tympanic membrane perforations (TMPs) healed spontaneously. However, the chronic TMPs require surgical intervention or other therapeutic interventions. So that researchers were developed, many different therapeutic applications by the tissue engineering approach (22-24). Among different approaches, the topical use of umbilical cord serum with biodegradable polymers, synthetic scaffolds and collagen nanofibers have been used to regenerate injured tympanic membrane. Jang et al. presented the first trial of UCS with three-dimensional collagen scaffolds to enhance the tympanic membrane healing process (6). This study revealed that the topical use of UCS with collagen bio scaffold might facilitate the fibroblasts ingrowth and extracellular matrix formation in the ruptured sites thus leading to an increased thickness of the tympanic membrane in the experimental group. Since cord serum has many growth factors within, it is combined with polycaprolactone/silk-fibroin scaffold to improve the closure rate of subacute TM perforation in guinea pigs (9). Therefore, cord serum emerges as a good choice of biological fluid in tissue engineering studies.

\section{UCS in Bone Regeneration}

Growth factors are playing a crucial role in regulation of bone formation and bone repair processes $(25,26)$. In clinical applications, commonly used exogenous growth factors are expensive and the extraction process complex as well. These limitations make researchers look into growth factor-rich sources. Among various biological fluids, cord serum has several bone regeneration-related growth factors for promoting cell proliferation, differentiation and cell migration. Hence, in in vitro cultures, cord serum has emerged as a new supplement for osteogenic induction in human mesenchymal stem cells (hMSCs) $(13,27,28)$. In in vivo research, human cord serum combined with scaffold material may be used to enhance the osteogenic process. Mastoid bone is one of the parts of temporal bone, located behind the ear. In the mastoid obliteration study, the use of UCS with polycaprolactone/ alginate scaffold greatly stimulate the bone regeneration (5). 
Therefore, the application of UCS not only promotes the wound healing process but also assists in stimulating new bone formation. However, several in vitro and in vivo studies are required to establish the use of cord serum in bone regenerative medicine.

\section{UCS in Nerve Regeneration}

During regeneration, nerve growth factor, neurotrophin-3, brain-derived neurotrophic factor, glial-derived neurotrophic factor, platelet-derived growth factor and other factors are playing a critical role in neuronal survival, neuronal growth, proliferation and differentiation (29). Since cord serum has been found to be rich in sources of various neurotrophic factors, it can be used to regenerate different types of neuronal cells in clinical applications. For example, glaucoma is a common eye disease that can damage the optic nerves and further lead to loss of vision. A preliminary study analyzed that topical administration of cord serum in glaucoma patients observed with better improvements in their visual field test parameters. This efficacy is assumed to be related with high growth factor amount of the cord serum, which possibly exerts a neuroprotective action on the optic nerves (30). In a rare ocular neurodegenerative disease, cord serum treated patients showed better improvement in their visual acuity, corneal sensitivity and epithelial healing rate (14). Recent advancements in tissue engineering, incorporation of cord serum with engineered scaffold has been emerged as a new option for nerve regeneration. In facial nerve regeneration study, a nerve fibrous conduit contains synthetic biodegradable material, collagen and human cord serum successfully applied for the regeneration of facial nerves in experimental animals (7). Therefore, cord serum components play a major role in nerve regeneration and neuroprotection.

\section{Clinical Uses of UCS}

Additionally, cord serum has been used as an effective supplement for in vitro cell culture as well as good diagnostic tool to predict an early progression of diseases $(11,31-33)$.

\section{Effective Supplement for In Vitro Cell Culture}

To date, fetal bovine serum (FBS) is believed to be the standard growth supplement in diverse cell culture applications. It contains enormous growth factors, vitamins, hormones, cell adhesive factors, extracellular matrix molecules and minerals that boost the cell attachment, as well as cell proliferation and differentiation. Even though it has lot of valuable sources, it has certain limitations in its use. To obtain blood from bovine fetus requires more animal sources and some ethical problems need to be resolved. Since FBS is an animal serum, the risk of contamination by bovine viruses, prions and bacteria especially by mycoplasma infections is higher. As well as, the presence of xenoproteins in bovine serum can trigger the adverse immunological responses to the growing cells on culture plate. Therefore, several investigators have established possible alternative sources for FBS in cell culture procedures. They found that, among several bloodderived growth additives, cord blood serum showed an equal or higher potential to FBS in stem cell cultures $(13,34)$. The key benefits of using cord serum are that it can be obtained easily and massively from umbilical cord blood after delivery without any ethical issues. It is free of animal origin pathogens and has remarkably lower immunogenicity. In recent years, cord blood serum is mainly preferred as a reasonable supplement for different sources-derived mesenchymal stem cells (bone-marrow mesenchymal stem cells, placenta-derived mesenchymal stem cells, Wharton's jelly mesenchymal stem cells and cord blood mesenchymal stem cells) proliferation, osteogenic and adipogenic differentiation and migration (13, 28, 33-35). Moreover, in fibroblast cell cultures, human cord serum potentially induces higher proliferation rate than FBS (36). For ocular surface epithelial cells (limbal, conjunctival, and cornea epithelial cells) proliferation and differentiation, cord serum is established as an effective and safer alternative growth media supplement in culture systems $(37,38)$. Additionally, Xia et al. described cord serum can increases the proliferation of human fetal islet-like cells when compared to fetal calf serum (FCS) (39). Hence, UCS can serve as a good alternative to FBS or FCS.

\section{Disease Diagnosis}

Cord blood serum may have certain molecular markers for early detection of specific diseases or estimation of severity and disease progression. For example, atopic dermatitis is the common inflammatory skin disease, characterized by the higher expression of several chemokine markers. Among them, CCL17 overexpression leads to development of atopic dermatitis (40). The presence of a higher level of CCL17 marker in umbilical cord serum may predict the onset of atopic dermatitis in infants (32). Perinatal asphyxia is a fatal condition in which a newborn baby's brain does not get enough oxygen during or after birth due to many causes. In this case, the level of interleukin-6 (IL-6) cytokine in umbilical cord serum can suggest an early diagnosis of brain dysfunction or disorder in neonates (10). Procalcitonin (PCT) is a peptide precursor of calcitonin hormone. Usually, PCT is not detectable in healthy adult serum. But during bacterial infection, PCT concentration noticeably increases in blood serum (41). In umbilical cord serum samples, higher level of PCT marker seems to be an important parameter for the diagnosis of early bacterial infection in newborn infants (31). Therefore, cord serum markers played an important role in an early detection of a disease. 


\section{Challenges of Using UCS}

So far, there have been reported no major clinical complications but possible adverse effects must always be considered when using cord serum. Though many laboratory examinations are carried out in cord blood donors, there is a possibility of transmission of blood-borne pathogens or blood-borne diseases (18). Moreover, incompatibility, allergic reactions and bacterial contamination are other possible complications (17). Cord blood can be obtained from multiple pregnant donors. Therefore, donor to donor blood variations must be completely eliminated by heat inactivation and other required processes (13). In addition, additional costs for serum preparation should also be taken into consideration (42). Avoiding frequent freeze-thaw cycles can preserve the cord serum efficacy in clinical applications.

\section{Conclusion and Future Applications}

Overall, due to the availability of numerous essential biological factors, cord serum can be recognized as a potent supplement in various clinical applications. Most of the investigators have performed the comparative analysis for the purpose of revealing the advantage of using cord blood serum with fetal bovine serum and other blood-derived supplements. In ophthalmologic field, cord serum is prepared in the form of eye drops because it is rich in various growth factors and neurotrophic factors. Therefore, it can be successfully applied in the treatment of many ocular diseases. But in other fields, the use of cord serum needs to be enhanced. Particularly in regenerative medicine, fewer studies are available for cord serum application. However, some have demonstrated a better outcome for tissue regeneration including bone regeneration, corneal epithelial tissue regeneration, tympanic membrane regeneration and nerve regeneration. In tissue engineering, the employment of bio scaffold materials incorporating cord serum is considered as the most promising approach to enhance wound healing and regeneration processes in experiment models. Further research in this area is required to establish cord serum therapeutic approach in clinical evaluation.

\section{Conflicts of Interest}

The Authors declare no conflicts of interest.

\section{Authors' Contributions}

Manuscript design, C.H.J.; reviewing, writing and editing, N.M., discussion and comments, C.H.J, J.H.C, G.W.C. All Authors have read and agreed to the published version of the manuscript.

\section{Acknowledgements}

This work was supported by Grants from the Basic Science Research Program through the National Research Foundation of Korea (NRF) funded by the Ministry of Education, Science and Technology (NRF-2018-R1D-1A1B07048074), National Research Foundation of Korea (NRF) funded by the Ministry of Science and ICT for Bioinspired Innovation Technology Development Project (NRF-2018M3C1B7021997) and the Korea Medical Device Development Fund grant funded by the Korea government (the Ministry of Science and ICT, the Ministry of Trade, Industry and Energy, the Ministry of Health \& Welfare, Republic of Korea, the Ministry of Food and Drug Safety) (Project Number: 202013C05).

\section{References}

1 Rocha V, Cornish J, Sievers EL, Filipovich A, Locatelli F, Peters C, Remberger M, Michel G, Arcese W, Dallorso S, Tiedemann K, Busca A, Chan KW, Kato S, Ortega J, Vowels M, Zander A, Souillet G, Oakill A, Woolfrey A, Pay AL, Green A, Garnier F, Ionescu I, Wernet P, Sirchia G, Rubinstein P, Chevret S and Gluckman E: Comparison of outcomes of unrelated bone marrow and umbilical cord blood transplants in children with acute leukemia. Blood 97(10): 2962-2971, 2001. PMID: 11342418. DOI: 10.1182/blood.v97.10.2962

2 Eapen M, Rubinstein P, Zhang MJ, Stevens C, Kurtzberg J, Scaradavou A, Loberiza FR, Champlin RE, Klein JP, Horowitz MM and Wagner JE: Outcomes of transplantation of unrelated donor umbilical cord blood and bone marrow in children with acute leukaemia: a comparison study. Lancet 369(9577): 19471954, 2007. PMID: 17560447. DOI: 10.1016/S0140-6736(07) 60915-5

3 Matsumoto $\mathrm{T}$ and Mugishima H: Non-hematopoietic stem cells in umbilical cord blood. Int J Stem Cells 2(2): 83-89, 2009. PMID: 24855525. DOI: 10.15283/ijsc.2009.2.2.83

4 Romanov YA, Vtorushina VV, Dugina TN, Romanov AY and Petrova NV: Human Umbilical Cord Blood Serum/Plasma: Cytokine Profile and Prospective Application in Regenerative Medicine. Bull Exp Biol Med 168(1): 173-177, 2019. PMID: 31761983. DOI: 10.1007/s10517-019-04670-2

5 Jang $\mathrm{CH}$, Cho YB, Choi CH, Jang YS, Jung WK, Lee H and Kim GH: Effect of umbilical cord serum coated 3D PCL/alginate scaffold for mastoid obliteration. Int J Pediatr Otorhinolaryngol 78(7): 1061-1065, 2014. PMID: 24788192. DOI: 10.1016/j.ijporl. 2014.04.004

6 Jang CH, Cho YB, Yeo M, Lee H, Min EJ, Lee BH and Kim GH: Regeneration of chronic tympanic membrane perforation using 3D collagen with topical umbilical cord serum. Int J Biol Macromol 62: 232-240, 2013. PMID: 24016669. DOI: 10.1016/j.ijbiomac. 2013.08.049

7 Jang $\mathrm{CH}$, Lee H, Kim M and Kim G: Effect of polycaprolactone/ collagen/hUCS microfiber nerve conduit on facial nerve regeneration. Int J Biol Macromol 93(Pt B): 1575-1582, 2016. PMID: 27086295. DOI: 10.1016/j.ijbiomac.2016.04.031

8 Jang YS, Jang $\mathrm{CH}$, Cho YB, Kim M and Kim GH: Tracheal regeneration using polycaprolactone/collagen-nanofiber coated with umbilical cord serum after partial resection. Int J Pediatr Otorhinolaryngol 78(12): 2237-2243, 2014. PMID: 25465447. DOI: $10.1016 /$ j.ijporl.2014.10.022 
9 Lee $\mathrm{H}$, Jang $\mathrm{CH}$ and $\mathrm{Kim} \mathrm{GH}$ : A polycaprolactone/silk-fibroin nanofibrous composite combined with human umbilical cord serum for subacute tympanic membrane perforation; an in vitro and in vivo study. J Mater Chem B 2(18): 2703-2713, 2014. PMID: 32261436. DOI: 10.1039/c4tb00213j

10 Chiesa C, Pellegrini G, Panero A, De Luca T, Assumma M, Signore F and Pacifico L: Umbilical cord interleukin-6 levels are elevated in term neonates with perinatal asphyxia. Eur J Clin Invest 33(4): 352-358, 2003. PMID: 12662167. DOI: 10. 1046/j.1365-2362.2003.01136.x

11 Shetty P, Bharucha K and Tanavde V: Human umbilical cord blood serum can replace fetal bovine serum in the culture of mesenchymal stem cells. Cell Biol Int 31(3): 293-298, 2007. PMID: 17208468. DOI: 10.1016/j.cellbi.2006.11.010

12 Esmaeli A, Moshrefi M, Shamsara A, Eftekhar-Vaghefi SH and Nematollahi-Mahani SN: Xeno-free culture condition for human bone marrow and umbilical cord matrix-derived mesenchymal stem/stromal cells using human umbilical cord blood serum. Int J Reprod Biomed 14(9): 567-576, 2016. PMID: 27738658

13 Hassan G, Kasem I, Soukkarieh C and Aljamali M: A Simple Method to isolate and expand human umbilical cord derived mesenchymal stem cells: using explant method and umbilical cord blood serum. Int J Stem Cells 10(2): 184-192, 2017. PMID: 28844128. DOI: $10.15283 / \mathrm{ijsc} 17028$

14 Yoon KC, You IC, Im SK, Jeong TS, Park YG and Choi J: Application of umbilical cord serum eyedrops for the treatment of neurotrophic keratitis. Ophthalmology 114(9): 1637-1642, 2007. PMID: 17382396. DOI: 10.1016/j.ophtha.2006.12.014

15 Tsubota K, Goto E, Shimmura S and Shimazaki J: Treatment of persistent corneal epithelial defect by autologous serum application. Ophthalmology 106(10): 1984-1989, 1999. PMID: 10519596. DOI: 10.1016/S0161-6420(99)90412-8

16 Yoon KC, Im SK, Park YG, Jung YD, Yang SY and Choi J: Application of umbilical cord serum eyedrops for the treatment of dry eye syndrome. Cornea 25(3): 268-272, 2006. PMID: 16633024. DOI: 10.1097/01.ico.0000183484.85636.b6

17 Vajpayee RB, Mukerji N, Tandon R, Sharma N, Pandey RM, Biswas NR, Malhotra N and Melki SA: Evaluation of umbilical cord serum therapy for persistent corneal epithelial defects. $\mathrm{Br}$ J Ophthalmol 87(11): 1312-1316, 2003. PMID: 14609821. DOI: 10.1136/bjo.87.11.1312

18 Yoon KC, Heo H, Im SK, You IC, Kim YH and Park YG: Comparison of autologous serum and umbilical cord serum eye drops for dry eye syndrome. Am J Ophthalmol 144(1): 86-92, 2007. PMID: 17493572. DOI: 10.1016/j.ajo.2007.03.016

19 Yoon KC, Heo H, Jeong IY and Park YG: Therapeutic effect of umbilical cord serum eyedrops for persistent corneal epithelial defect. Korean J Ophthalmol 19(3): 174-178, 2005. PMID: 16209277. DOI: 10.3341/kjo.2005.19.3.174

20 Yoon KC, Jeong IY, Im SK, Park YG, Kim HJ and Choi J: Therapeutic effect of umbilical cord serum eyedrops for the treatment of dry eye associated with graft-versus-host disease. Bone Marrow Transplant 39(4): 231-235, 2007. PMID: 1721 1430. DOI: $10.1038 /$ sj.bmt.1705566

21 Giannaccare G, Fresina M, Vagge A and Versura P: Synergistic effect of regenerating agent plus cord blood serum eye drops for the treatment of resistant neurotrophic keratitis: a case report and a hypothesis for pathophysiologic mechanism. Int Med Case Rep J 8: 277-281, 2015. PMID: 26586967. DOI: 10.2147/IMCRJ. S89968
22 Maharajan N, Cho GW and Jang CH: Application of mesenchymal stem cell for tympanic membrane regeneration by tissue engineering approach. Int J Pediatr Otorhinolaryngol 133: 109969, 2020. PMID: 32126416. DOI: 10.1016/j.ijporl.2020.109969

23 Teh BM, Marano RJ, Shen Y, Friedland PL, Dilley RJ and Atlas MD: Tissue engineering of the tympanic membrane. Tissue Eng Part B Rev 19(2): 116-132, 2013. PMID: 23031158. DOI: 10.1089/ ten.TEB.2012.0389

24 Villar-Fernandez MA and Lopez-Escamez JA: Outlook for Tissue Engineering of the Tympanic Membrane. Audiol Res 5(1): 117, 2015. PMID: 26557361. DOI: 10.4081/audiores.2015.117

25 Baylink DJ, Finkelman RD and Mohan S: Growth factors to stimulate bone formation. J Bone Miner Res 8(Suppl 2): S565572, 1993. PMID: 8122528. DOI: 10.1002/jbmr.5650081326

26 Devescovi V, Leonardi E, Ciapetti G and Cenni E. Growth factors in bone repair. Chir Organi Mov 92(3): 161-168, 2008. PMID: 19043663. DOI: 10.1007/s12306-008-0064-1

27 Jung J, Moon N, Ahn JY, Oh EJ, Kim M, Cho CS, Shin JC and Oh IH: Mesenchymal stromal cells expanded in human allogenic cord blood serum display higher self-renewal and enhanced osteogenic potential. Stem Cells Dev 18(4): 559-571, 2009. PMID: 18754716. DOI: $10.1089 / \mathrm{scd} .2008 .0105$

28 Tekkatte C, Vidyasekar P, Kapadia NK and Verma RS: Enhancement of adipogenic and osteogenic differentiation of human bone-marrow-derived mesenchymal stem cells by supplementation with umbilical cord blood serum. Cell Tissue Res 347(2): 383-395, 2012. PMID: 22311206. DOI: 10.1007/s00441-012-1328-5

29 Li R, Li DH, Zhang HY, Wang J, Li XK and Xiao J: Growth factors-based therapeutic strategies and their underlying signaling mechanisms for peripheral nerve regeneration. Acta Pharmacol Sin 41(10): 1289-1300, 2020. PMID: 32123299. DOI: $10.1038 / \mathrm{s} 41401-019-0338-1$

30 Campos E, Versura P, Giannaccare G, Terzi A, Bisti S, Di Marco $S$ and Buzzi M: Topical treatment with cord blood serum in glaucoma patients: a preliminary report. Case Rep Ophthalmol Med 2018: 2381296, 2018. PMID: 30147975. DOI: 10.1155/ 2018/2381296

31 Kordek A, Giedrys-Kalemba S, Pawlus B, Podraza W and Czajka $\mathrm{R}$ : Umbilical cord blood serum procalcitonin concentration in the diagnosis of early neonatal infection. J Perinatol 23(2): 148-153, 2003. PMID: 12673266. DOI: 10.1038/sj.jp.7210885

32 Miyahara H, Okazaki N, Nagakura T, Korematsu S and Izumi T: Elevated umbilical cord serum TARC/CCL17 levels predict the development of atopic dermatitis in infancy. Clin Exp Allergy 41(2): 186-191, 2011. PMID: 21054588. DOI: 10.1111/j.13652222.2010.03634.x

33 Phadnis SM, Joglekar MV, Venkateshan V, Ghaskadbi SM, Hardikar AA and Bhonde RR: Human umbilical cord blood serum promotes growth, proliferation, as well as differentiation of human bone marrow-derived progenitor cells. In Vitro Cell Dev Biol Anim 42(10): 283-286, 2006. PMID: 17316059. DOI: $10.1290 / 0512087.1$

34 Samareh Salavati Pour M, Vahidi R, Lashkari M, Derakhshani A, Ameri Z and Farsinejad A: Cord blood serum harvesting by hydroxyethyl starch: a fetal bovine serum alternative in expansion of umbilical cord-derived mesenchymal stem cells. Cytotechnology 72(4): 551-567, 2020. PMID: 32601794. DOI: 10.1007/s 10616-020-00404-9 
35 Wang L, Yang Y, Zhu Y, Ma X, Liu T, Zhang G, Fan H, Ma L, Jin Y, Yan X, Wei J and Li Y: Characterization of placenta-derived mesenchymal stem cells cultured in autologous human cord blood serum. Mol Med Rep 6(4): 760-766, 2012. PMID: 22824952. DOI: $10.3892 / \mathrm{mmr} .2012 .1000$

36 Rungsiwiwut $R$, Ingrungruanglert $P$, Numchaisrika $P$, Virutamasen $\mathrm{P}$, Phermthai $\mathrm{T}$ and Pruksananonda K: Human Umbilical Cord Blood-Derived Serum for Culturing the Supportive Feeder Cells of Human Pluripotent Stem Cell Lines. Stem Cells Int 2016: 4626048, 2016. PMID: 26839561. DOI: 10.1155/2016/4626048

37 Ang LP, Do TP, Thein ZM, Reza HM, Tan XW, Yap C, Tan DT and Beuerman RW: Ex vivo expansion of conjunctival and limbal epithelial cells using cord blood serum-supplemented culture medium. Invest Ophthalmol Vis Sci 52(9): 6138-6147, 2011. PMID: 21474776. DOI: 10.1167/iovs.10-6527

38 Chakraborty A, Dutta J, Das S and Datta H: Effect of cord blood serum on ex vivo human limbal epithelial cell culture. J Ocul Biol Dis Infor 5(3-4): 77-82, 2013. PMID: 24596943. DOI: $10.1007 / \mathrm{s} 12177-013-9106-5$

39 Xia D, He HY, Lei ZM, Zhang PM and Guo Y: Effects of human umbilical cord serum on proliferation and insulin content of human fetal islet-like cell clusters. Hepatobiliary Pancreat Dis Int 3(1): 144-148, 2004. PMID: 14969859

40 Furue M, Ulzii D, Vu YH, Tsuji G, Kido-Nakahara M and Nakahara T: Pathogenesis of Atopic Dermatitis: Current Paradigm. Iran J Immunol 16(2): 97-107, 2019. PMID: 31182684. DOI: $10.22034 / \mathrm{IJI} .2019 .80253$

41 Assicot M, Gendrel D, Carsin H, Raymond J, Guilbaud J and Bohuon C: High serum procalcitonin concentrations in patients with sepsis and infection. Lancet 341(8844): 515-518, 1993. PMID: 8094770. DOI: 10.1016/0140-6736(93)90277-n

42 Yoon KC: Use of umbilical cord serum in ophthalmology. Chonnam Med J 50(3): 82-85, 2014. PMID: 25568842. DOI: 10.4068/cmj.2014.50.3.82

43 Hoeben A, Landuyt B, Highley MS, Wildiers H, Van Oosterom AT and De Bruijn EA: Vascular endothelial growth factor and angiogenesis. Pharmacol Rev 56(4): 549-580, 2004. PMID: 15602010. DOI: $10.1124 /$ pr.56.4.3

44 Gospodarowicz D, Neufeld G and Schweigerer L: Fibroblast growth factor. Mol Cell Endocrinol 46(3): 187-204, 1986. PMID: 2427371. DOI: 10.1016/0303-7207(86)90001-8

45 Buzzi M, Versura P, Grigolo B, Cavallo C, Terzi A, Pellegrini M, Giannaccare G, Randi V and Campos EC: Comparison of growth factor and interleukin content of adult peripheral blood and cord blood serum eye drops for cornea and ocular surface diseases. Transfus Apher Sci 57(4): 549-555, 2018. PMID: 29929885. DOI: 10.1016/j.transci.2018.06.001

46 Seo KW, Sohn SY, Bhang DH, Nam MJ, Lee HW and Youn HY: Therapeutic effects of hepatocyte growth factor-overexpressing human umbilical cord blood-derived mesenchymal stem cells on liver fibrosis in rats. Cell Biol Int 38(1): 106-116, 2014. PMID: 24115681. DOI: 10.1002/cbin.10186

47 Jia L, Zhou X, Huang X, Xu X, Jia Y, Wu Y, Yao J, Wu Y and Wang K: Maternal and umbilical cord serum-derived exosomes enhance endothelial cell proliferation and migration. FASEB J 32(8): 4534-4543, 2018. PMID: 29570394. DOI: 10.1096/fj.2017 01337RR
48 Barker PA, Mantyh P, Arendt-Nielsen L, Viktrup L and Tive L: Nerve growth factor signaling and its contribution to pain. J Pain Res 13: 1223-1241, 2020. PMID: 32547184. DOI: 10.2147/ JPR.S247472

49 Krstic J, Trivanovic D, Obradovic H, Kukolj T, Bugarski D and Santibanez JF: Regulation of mesenchymal stem cell differentiation by transforming growth factor beta superfamily. Curr Protein Pept Sci 19(12): 1138-1154, 2018. PMID: 29150917. DOI: $10.2174 / 1389203718666171117103418$

$50 \mathrm{Xu}$ X, Zheng L, Yuan Q, Zhen G, Crane JL, Zhou X and Cao X: Transforming growth factor- $\beta$ in stem cells and tissue homeostasis. Bone Res 6: 2, 2018. PMID: 29423331. DOI: 10.1038/s41413017-0005-4

51 Han SB, Liu YC, Mohamed-Noriega K and Mehta JS: Application of novel drugs for corneal cell regeneration. J Ophthalmol 2018: 1215868, 2018. PMID: 29854423. DOI: $10.1155 / 2018 / 1215868$

52 Youssef A, Aboalola D and Han VK: The Roles of insulin-like growth factors in mesenchymal stem cell niche. Stem Cells Int 2017: 9453108, 2017. PMID: 28298931. DOI: 10.1155/2017/9453108

53 Hassan HT and Zander A: Stem cell factor as a survival and growth factor in human normal and malignant hematopoiesis. Acta Haematol 95(3-4): 257-262, 1996. PMID: 8677752. DOI: $10.1159 / 000203893$

54 Heidemann J, Ogawa H, Dwinell MB, Rafiee P, Maaser C, Gockel HR, Otterson MF, Ota DM, Lugering N, Domschke W and Binion DG: Angiogenic effects of interleukin 8 (CXCL8) in human intestinal microvascular endothelial cells are mediated by CXCR2. J Biol Chem 278(10): 8508-8515, 2003. PMID: 12496258. DOI: $10.1074 / \mathrm{jbc} . M 208231200$

55 Baggiolini M and Clark-Lewis I: Interleukin-8, a chemotactic and inflammatory cytokine. FEBS Lett 307(1): 97-101, 1992. PMID: 1639201. DOI: 10.1016/0014-5793(92)80909-z

56 Goswami R and Kaplan MH: A brief history of IL-9. J Immunol 186(6): 3283-3288, 2011. PMID: 21368237. DOI: 10.4049/ jimmunol.1003049

57 Wolf SF, Sieburth D and Sypek J: Interleukin 12: a key modulator of immune function. Stem Cells 12(2): 154-168, 1994. PMID: 7911046. DOI: 10.1002/stem.5530120203

58 Kuwabara T, Ishikawa F, Kondo M and Kakiuchi T: The role of IL-17 and related cytokines in inflammatory autoimmune diseases. Mediators Inflamm 2017: 3908061, 2017. PMID: 28316374. DOI: $10.1155 / 2017 / 3908061$

59 Liu M, Guo S, Hibbert JM, Jain V, Singh N, Wilson NO and Stiles JK: CXCL10/IP-10 in infectious diseases pathogenesis and potential therapeutic implications. Cytokine Growth Factor Rev 22(3): 121130, 2011. PMID: 21802343. DOI: 10.1016/j.cytogfr.2011.06.001

60 Sokol CL and Luster AD: The chemokine system in innate immunity. Cold Spring Harb Perspect Biol 7(5): 2015. PMID: 25635046. DOI: 10.1101/cshperspect.a016303

61 Barrientos S, Stojadinovic O, Golinko MS, Brem H and TomicCanic M: Growth factors and cytokines in wound healing. Wound Repair Regen 16(5): 585-601, 2008. PMID: 19128254. DOI: 10.1111/j.1524-475X.2008.00410.x

Received December 13, 2020

Revised January 25, 2021

Accepted February 1, 2021 